\title{
The Impact of State Budget Revenue on Economic Growth: A Case of Vietnam
}

\author{
Hieu Huu NGUYEN ${ }^{1}$
}

Received: July 14, 2019 Revised: September 16, 2019 Accepted: September 24, 2019

\begin{abstract}
This paper is intended to study the relationship between state budget revenue and economic growth in Vietnam. The ordinary leastsquares regression method is used with secondary data collected from General Statistics Office of Vietnam in the period of 20002017. Vietnamese state budget revenue includes domestic revenue (excluding oil revenue), oil revenue, custom duty revenue, and grants. The testing result shows that the state budget revenue has a positive correlation with economic growth of Vietnam. However, the components of state budget revenue have different levels of impact on the economy. Domestic revenue and oil revenue are statistically significant and have a positive effect on the economy, while the impact of custom duty revenue and grants on the economy is invisible. Vietnamese state budget revenue should be restructured toward the sustainability and by way of boosting the economy, specifically: (1) Increase the proportion of domestic revenue to state budget revenue and domestic revenue should be based on the ground of production and business activities rather than collection from state-owned assets; (2) Reduce the proportion of custom duty revenue and grants to state budget revenue; (3) Keep the volume and ratio of oil revenue in state budget revenue at an appropriate proportion.
\end{abstract}

Keywords : State Budget, State Budget Revenue, Economic Growth, Vietnam

JEL Classification Code : H2O, H27, H61, O11

\section{Introduction}

Vietnam has been transforming to a market economy from a centrally-planned economy. The state's intervention in the economy has also been shifting from direct to indirect control through macroeconomic instruments which are fiscal policy and monetary policy. The state budget revenue, a part of the fiscal policy, has been focused by the Vietnamese government in order to create financial resources to meet the spending needs, to regulate and promote economic development.

According to Law on State budget of Vietnam, the state budget revenue refers to revenue of the government financed from domestic production, business and service

1 First Author and Corresponding Author, Dean, Fundamental Faculty, Audit Training Institute, State Audit Office of Vietnam. [Postal Address: 111 Tran Duy Hung Street, Cau Giay District, Hanoi, 100000, Vietnam] Email: hieunh@sav.gov.vn and nguyenhuuhieuktnn@gmail.com

(c) Copyright: Korean Distribution Science Association (KODISA)

This is an Open Access article distributed under the terms of the Creative Commons Attribution Non-Commercial License (http://Creativecommons.org/licenses/by-nc/4.0/) which permits unrestricted noncommercial use, distribution, and reproduction in any medium, provided the original work is properly cited. establishments or citizens and other revenues from abroad. There are many ways to categorize state budget revenue. Government revenue can be classified into tax and non-tax revenue (Muriithi, 2013), oil and non-oil revenue (Raifu \& Raheem, 2018). In this paper, the author divides state budget revenue based on its sources, which is in line with Law on State budget and Statistical Yearbook of Vietnam. Accordingly, Vietnamese state budget revenue includes four items: domestic revenue (excluding oil revenue), oil revenue, custom duty revenue and grants.

State budget revenue-to-GDP ratio and the structure of revenues have important meanings. An appropriate ratio will nurture the collection sources, create the sustainability of the state budget revenue. In the contrary, the extremely high or low ratio will hold back the growth of the economy. The revenue structure reflects the corresponding proportion of each revenue component to total state budget revenue. The impact of revenue items on the economy differs because they are orginated from different revenue bases. Changing the revenue structure in an appropriate way will have a positive impact on the economy. Given the above, there are many important questions on state budget revenue of Vietnam, specifically: Whether the state budget revenue of 
Vietnam has positive impact on the economy? In the structure of state budget revenue, which revenue items are meant to promote the economy? Which revenue items are not? The following research will search for answers.

\section{Literature Review}

The relationship between the state budget revenue (in whole or in part) and economic growth has been studied by many scholars from different perspectives with different results being given.

Ofoegbu and Akwu (2016) researched state budget revenue from the perspective of its main source, taxes. They examined the effect of tax revenue on the economic development of Nigeria. Ordinary least-squares regression technique was used with time series data for the period 2005-2014. The result showed that tax revenue had significant and positive influence on economy. Tax revenue also had significant and positive impact on human development index of Nigeria. Thus tax revenue was an instrument for economic growth in Nigeria. When studying the relationship between tax revenue and economic growth of Ghana for period 1986 - 2010, Takumah (2014) had the same result. The statistical analysis confirmed that "there exists uni-directional causality between tax revenue and economic growth and the flow of causality is through tax revenue to economic growth in Ghana" (Takumah, 2014, p.22). Based on his research, Takumah (2014) is of opinion that Ghanaian government should enforce the tax revenue mobilization to meet the demand of infrastructure building for development. The enforcement was reflected by the expansion of tax base and reduction of tax rates.

Similarly, by approaching the state budget revenue from its main source namely taxes, Dladla and Khobai (2018) however gave a different result with Ofoegbu and Akwu (2016) and Takumah (2014). Dladla and Khobai used autoregressive distribution lag approach to find the relation between the taxes and economic growth in South Africa for the period 1981-2016. The empirical results indicated that the impact of taxes on economic growth in South Africa was negative and significant in the short-run and long-run. A $1 \%$ increase in taxes would decrease economic growth by $0.01 \%$. Romer and Romer (2010) also investigated the impact of tax changes on economic growth of America. Their results were in line with Dladla and Khobai (2018). Tax changes had very large effects on American economic growth. A tax increase of 1\% GDP lowered real GDP almost 3\%.

Nantob (2014) studied the relationship between four categories of taxes namely taxes revenue; taxes on goods and services; taxes on income, profits, and capital gains; and tax on international trade and economic growth of 47 developing countries in the period 2000-2012. The result showed that there were both a positive relationship and a non-linear relationship between taxes revenue and economic growth. The result also suggested both a negative relationship and a non-linear (U-shaped) relationship between taxes on income, profits, and capital gains and economic growth. The last two categories of taxes: taxes on goods and services and taxes on international trade had a negative relationship and a non-linear relationship with economic growth.

Researching on the relationship between taxation and economic growth in Nigeria for the period 1980-2013, Babatunde and Ibukun (2016) confirmed that in the long-run (but not short-run) the relationship between tax and economic growth would exist. The key components of tax had the different impacts on Nigeria's economy. Petroleum profit tax and company income tax were positively related to real GDP. On the other hand, the relationship between custom and excise duties and economic growth was negative. Taken together, the tax components did not significantly affect Nigerian economic growth.

Muriithi (2013) had a broader approach where he classified Kenyan government revenues into tax and non-tax revenue; tax revenue comprises import duty, excise duty, income tax, and value added tax. Annual data was collected from 1992 to 2011 and analyzed by SPSS to examine the relationship between government revenues and economic growth in Kenya. The result showed that government revenues had positive effects on Kenyan economic growth. The components of government revenues had different impacts. There was an inverse relationship between economic growth and import duty. The study also concluded that increase in excise duty reduced the rate of economic growth. Income tax led to continuous increase in revenue collected by government and there was a direct relationship between income tax and economic growth. Value added tax also had positive effect on economy. The study finding concluded that non-tax revenue had a direct relationship with economic growth.

Raifu and Raheem (2018) had a different approach when researching the impact of government revenues on Nigerian economic growth for the period 1983-2013. They divided government revenues into oil and non-oil revenues to assess deeply the role of oil revenue because Nigeria is one of oil producing countries in the world. The results revealed that all revenues (total revenue, oil revenue and non-oil revenue) had positive effects on economic growth in both the shortrun and long-run. A $1 \%$ increase in government total revenue, oil revenue, and non-oil revenue led to $0.12 \%$, $0.118 \%$ and $0.092 \%$ increase in Nigerian economic growth respectively.

Gnangnon (2017) had a study on the relationship between multilateral trade liberalization and government revenue. In his empirical analysis on data collected from 169 countries in period 1995-2013, it was proven that multilateral trade liberalization had positive impact on government revenue in medium and long term. This result was especially applicable to least-developed countries. Gnangnon (2017) was of the opinion that the restrictions on international trade would negatively impact the government revenue. 


\section{Research Methodology}

This paper uses ordinary least-squares technique to research the relationship between state budget revenue and economic growth of Vietnam in the period 2000-2017. Secondary data is taken from Statistical Yearbook of Vietnam published by General Statistics Office of Vietnam. A regression model is built where independent variable is GDP and four dependent variables are components of state budget revenues (domestic revenue, $\mathrm{cu}$ stom duty revenue, oil revenue, and grants).

The model is expressed as follows:

$\mathrm{GDP}=\beta_{1}+\beta_{2} \mathrm{DOM}+\beta_{3} \mathrm{CUS}+\beta_{4} \mathrm{OIL}+\beta_{5} \mathrm{GRA}+\mathrm{u}$

where

$\beta 1$ : Intercept of the regression line. It implies any level of economy at zero state budget revenue.

$\beta_{2}, \beta_{3}, \beta_{4}, \beta_{5}$ : Coefficients to be estimated. They measure the effects of domestic revenue, custom duty revenue, oil revenue, and grants on GDP, respectively.

DOM: Domestic revenue (excluding oil revenue)

CUS: Custom duty revenue

OIL: Oil revenue.

GRA: Grants $\mathrm{u}$ : stochastic variable to accommodate the influence of other determinants of economy not included in the model.

Five hypotheses are set up based on regression results to test the impact of state budget revenue and the components of state budget revenue on the economy.

Hypothesis 1: Whether the population regression function is significant or not

Hypothesis 2: Whether DOM impacts GDP or not

Hypothesis 3: Whether CUS impacts GDP or not.

Hypothesis 4: Whether OIL impacts GDP or not

Hypothesis 5: Whether GRA impacts GDP or not

\section{Empirical Results}

Based on the data collected from the General Statistics Office of Vietnam from 2000 to 2017 and using Eviews 10.0 software, the regression result is shown in the following Table 1.

Table 1: Result of regression

\begin{tabular}{|l|l|l|l|c|}
\hline Variable & Coefficient & Std. Error & t-Statistic & Prob. \\
\hline C & -90050.96 & 110920.9 & -0.811848 & 0.4315 \\
DOM & 4.529674 & 0.494221 & 9.165277 & 0.0000 \\
CUS & 1.774227 & 3.256497 & 0.544827 & 0.5951 \\
OIL & 5.918281 & 2.248376 & 2.632247 & 0.0207 \\
GRA & 4.327904 & 34.86252 & 0.124142 & 0.9031 \\
\hline R-squared & 0.989120 & F-statistic & & 295.4720 \\
Adjusted R-squared & 0.985773 & Prob(F-statistic) & 0.000000 \\
S.E. of regression & 187998.7 & Mean dependent var & & 2127494. \\
Sum squared resid & $4.59 E+11$ & S.D. dependent var & & 1576137. \\
Log likelihood & -241.2075 & & \\
\hline
\end{tabular}

$\mathrm{GDP}=-90050.96+4.529674 \mathrm{DOM}+1.774227 \mathrm{CUS}+$ 5.918281 OIL + 4.327904 GRA

With the regression results obtained, statistical hypotheses are tested to have a more thorough assessment on the impact of state budget revenue and its components on Vietnamese economy.

Hypothesis 1: Whether the population regression function is significant or not

$\mathrm{H}_{0}: \mathrm{R}^{2}=0$ (The population regression function is not significant)

$\mathrm{H}_{1}: \mathrm{R}^{2} \neq 0$ (The population regression function is significant)

F-statistic is used to test. With number of observations (n) $=18$, number of variables $(\mathrm{k})=5$, and significance level $(\alpha)$ $=0.05$, the result of $\mathrm{F}$ is $295.4720>\mathrm{F}_{\alpha}(\mathrm{k}-1 ; \mathrm{n}-\mathrm{k})=3.06$.

Based on above results, $\mathrm{H}_{0}$ is rejected, therefore, $\mathrm{H}_{1}$ is accepted The significance of regression function shows that the state budget revenue has significant positive effect on GDP. The regression results also indicate that independent variables included in the model (DOM, CUS, OIL, and GRA) explain about $98.912 \%(\mathrm{R}$-squared $=0.98912)$ variations in the dependent variable (GDP). Hence, only $1.088 \%$ variability in GDP is explained by other factors outside domestic revenue, custom duty revenue, oil revenue, and grants.

Hypothesis 2: Whether DOM impacts GDP or not

$\mathrm{H}_{0}: \beta_{2}=0$ (DOM does not impact on GDP)

$\mathrm{H}_{1}: \beta_{2} \neq 0$ (DOM impacts on GDP)

T-statistic is used to test. With number of observations (n) $=18$, number of variables $(\mathrm{k})=5$, and significance level $(\alpha)$ $=0.05$, the result of $\mathrm{T}$ is $9.165277>t_{\alpha / 2}^{(n-k)}=2.16$.

The result indicates that $\mathrm{H}_{0}$ is rejected, thereby confirming that explanatory variable DOM has positive 
effect on explained variable GDP.

Hypothesis 3: Whether CUS impacts GDP or not.

$\mathrm{H}_{0}: \beta_{3}=0$ (CUS does not impact on GDP)

$\mathrm{H}_{1}: \beta_{3} \neq 0$ (CUS impacts on GDP)

T-statistic is used to test. With number of observations (n) $=18$, number of variables $(\mathrm{k})=5$, and significance level $(\alpha)$ $=0.05$, the result of $\mathrm{T}$ is $0.544827<t_{\alpha / 2}^{(n-k)}=2.16$.

The above result indicates that $\mathrm{H}_{0}$ is not rejected. There is insufficient evidence to conclude that the explanatory variable CUS impacts on the explained variable, namely GDP.

Hypothesis 4: Whether OIL impacts GDP or not

$\mathrm{H}_{0}: \beta_{4}=0$ (OIL does not impact on GDP)

$\mathrm{H}_{1}: \beta_{4} \neq 0$ (OIL impacts on GDP)

T-statistic is used to test. With number of observations (n) $=18$, number of variables $(\mathrm{k})=5$, and significance level $(\alpha)$ $=0.05$, the result of $\mathrm{T}$ is $2.632247>t_{\alpha / 2}^{(n-k)}=2.16$.

The result indicates that $\mathrm{H}_{0}$ is rejected, thereby confirming that explanatory variable OIL has positive effect on explained variable GDP.

Hypothesis 5: Whether GRA impacts GDP or not

$\mathrm{H}_{0}: \beta_{5}=0$ (GRA does not impact on GDP)

$\mathrm{H}_{1}: \beta_{5} \neq 0$ (GRA impacts on GDP)

T-statistic is used to test. With number of observations (n) $=18$, number of variables $(\mathrm{k})=5$, and significance level $(\alpha)$ $=0.05$, the result of $\mathrm{T}$ is $0.124142<t_{\alpha / 2}^{(n-k)}=2.16$.

The above result indicates that $\mathrm{H}_{0}$ is not rejected. There is insufficient evidence to conclude that the explanatory variable GRA impacts on the explained variable GDP.

In conclusion, the results of statistical hypothesis tests reveal that the state budget revenue, domestic revenue and oil revenue have positive effect on economic growth of Vietnam while the influence of custom duty revenue and grants on the economy is invisible.

\section{Discussion}

State budget revenue impacts the economy through the transmission mechanism. The state mobilizes a part of the financial resources of the economy to maintain the government apparatus and develop the investment. The revenue-to-GDP ratio has important implications for economic development (see Figure 1). The reasonable rates will encourage investment and nurture revenue resources for the state budget. If the mobilization rate is too high, the enterprises will consider withdrawing their investment or divert investment to other countries to ensure the expected profit. On the contrary, if the ratio is low, it will be hard to mobilize enough financial resources to meet the state's spending needs. Government must consider and determine an appropriate ratio to not only mobilize resources to meet spending needs but also encourage enterprises to invest and expand production and business.

The state budget revenue also has impacts on the economy through the government's encouragement or restraint of a particular industry or sector according to its development orientation. The government must determine appropriately the comparative advantages of industries or sectors whereby it can give priority to highly profitable industries and sectors and restrict unprofitable activities.

Another channel to transmit the impact of state budget revenue on the economy is government spending. State budget revenue is a basis for state budget expenditure. Thanks to having enough fund, the government provides necessary public goods and services, creates a favorable legal environment, builds infrastructure such as roads, bridges and ports, etc. for the economic development.

State budget revenue of Vietnam accounted for a large proportion of GDP, which was $25 \%$ on average for the period 2000-2017. The year-over-year growth rate of state budget revenue was $17.2 \%$ on average, which was much higher than the average economic growth rate for the period 2000-2017 of $6.76 \%$ (see Figure 1). State budget revenue basically met the demand of the government in ensuring the operation of the government apparatus. However, Vietnam was under great pressure to increase state budget revenue to build infrastructure. State budget deficit was relatively high in some periods (2014: 6.33\% GDP; 2015: 6.28\% GDP; and 2016: $5.52 \%$ GDP), which affected the sustainability of the state budget and national financial security. Increasing state budget revenue is bound by various factors and an inappropriate revenue increase policy may cause negative consequences on the economy. Result of regression and statistical tests for the period 2000-2017 shows that state budget revenue of Vietnam has a positive impact on the economy, in line with the research results of Ofoegbu and Akwu (2016), Takumah (2014), Muriithi (2013) and Raifu and Raheem (2018). However, the high revenue-to-GDP ratio and the high annual growth rate in state budget revenue might not actually encourage private investment. The reduction of revenue-to-GDP ratio of Vietnam may increase the state budget revenue. 


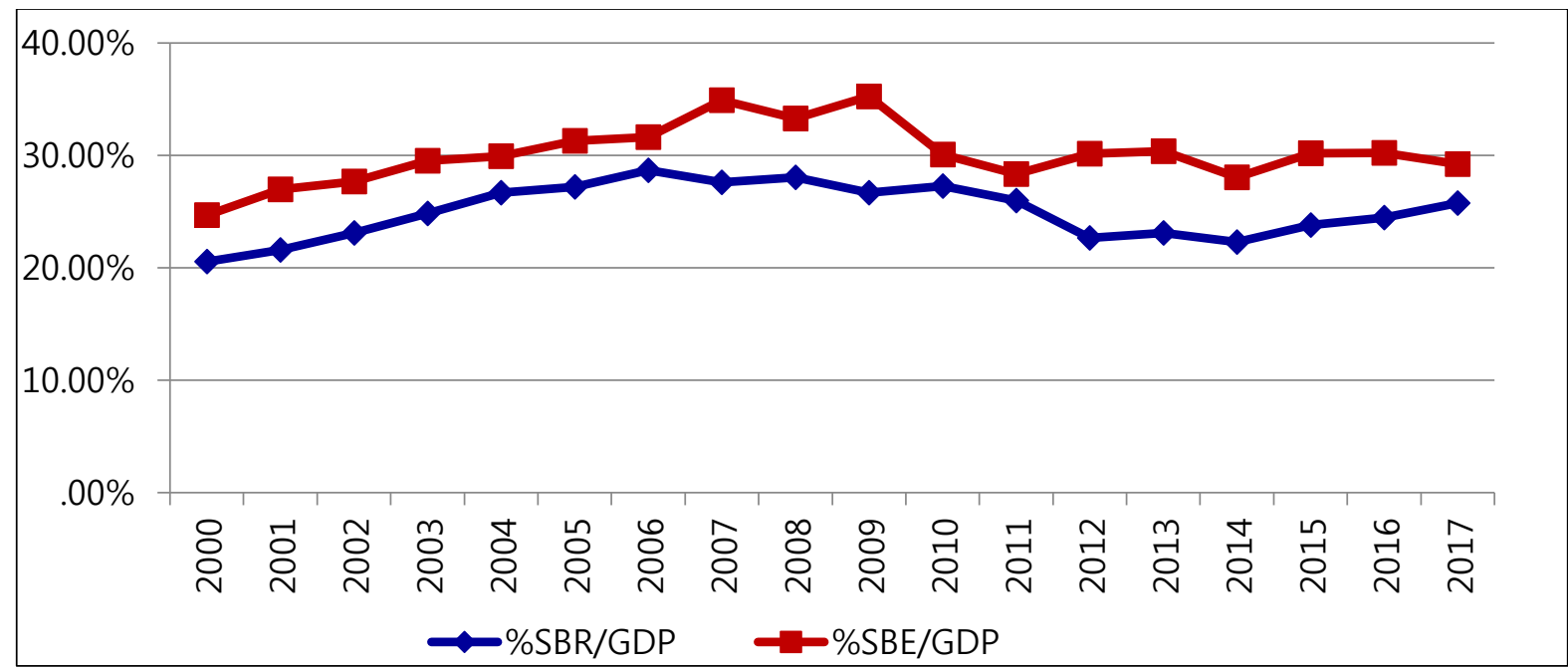

Source: General Statistics Office of Vietnam

Note: - \%SBR/GDP: State budget revenue-to-GDP ratio

- \%SBE/GDP: State budget expenditure-to-GDP ratio

Figure 1: The ratio of state budget revenue and state budget expenditure to GDP of Vietnam

Domestic revenue (excluding oil revenue) is the main stream of the Vietnamese state budget. Domestic revenue accounted for an average of $60.9 \%$ of the state budget revenue during the period 2000-2017. In recent years, the proportion of domestic revenue to state budget revenue has increased sharply, reaching the highest ratio in 2017 at $80.1 \%$ (see Figure 2). The domestic revenue-to-GDP ratio for the period 2000-2017 was $15.2 \%$ on average. The result of statistical tests shows that domestic revenue has a positive and significant impact on economic growth of Vietnam.
Domestic revenue is the collection reflecting the revenue derived from production and business activities and the exploitation of state-owned assets. Unlike oil revenue, custom duty revenue, and grants, domestic revenue is not directly influenced by offshore fluctuations. Therefore, domestic revenue closely reflects the real situation of the Vietnamese economy. The increase in domestic revenue is an indicator of not only economic development but also the sustainability of the state budget revenue.

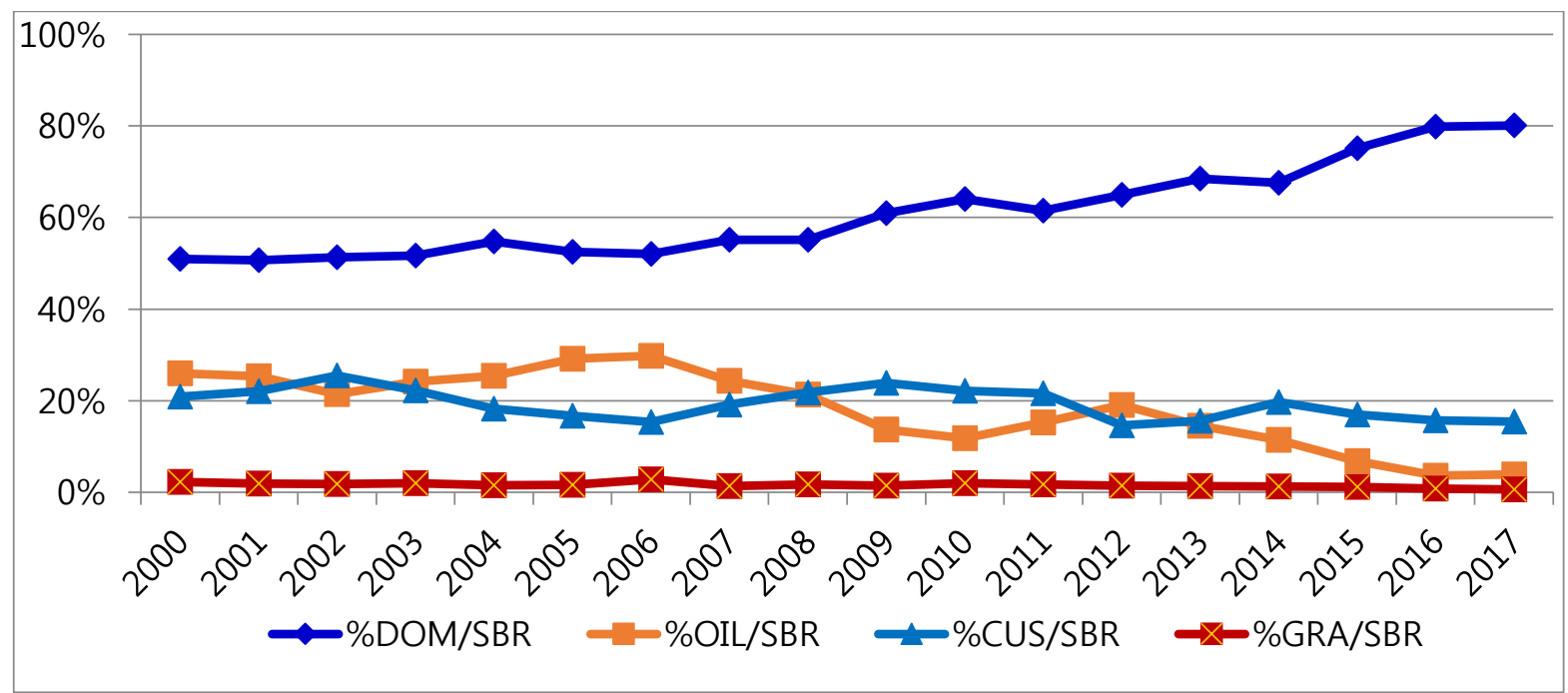

Source: General Statistics Office of Vietnam

"Note: - \%DOM/SBR: Domestic revenue-to-state budget revenue ratio

- \%CUS/SBR: Custom duty revenue-to-state budget revenue ratio

- \% OIL/SBR: Oil revenue-to-state budget revenue ratio

- \% GRA/SBR: Grants-to-state budget revenue ratio

Figure 2: The structure of Vietnamese state budget revenue 
Domestic revenue is composed of a lot of collection channels, of which the main sources include revenue from state-owned enterprises, revenue from foreign-invested enterprises, revenue from non-state sector, fees, revenue from land and houses.

Revenue from state-owned enterprises is the largest stream in the domestic revenue, accounting for $30.8 \%$ on average for the period 2000-2017. According to Law on Enterprise of Vietnam, state-owned enterprise is any enterprise of which $100 \%$ charter capital is held by the state. Currently, Vietnam has 1,204 state-owned enterprises, accounting for $0.2 \%$ of total enterprises operating in Vietnam (see Table 2). Along with the economic restructuring process, Vietnam has implemented the policy of equitization and divestment in state-owned enterprises. This is the main reason why revenue from state-owned enterprises tends to decrease in both quantity and proportion in total domestic revenue.

Revenue from foreign-invested enterprises has positive changes, reaching $16.4 \%$ of total domestic revenue for the period 2000-2017 on average. Foreign-invested enterprises include enterprises with capital directly invested by foreigners. There are two main types of foreign-invested enterprises: $100 \%$ foreign invested enterprises and joint ventures between foreign parties and domestic partners. Foreign direct investment activities have officially started since Vietnam issued the first Law on Foreign investment in 1987. After more than 30 years, the foreign-invested sector in Vietnam has been growing strongly and making positive contributions to Vietnam's economy. By the end of 2017, Vietnam attracted US\$ 319.6 billion of foreign direct investment capital with 16,178 foreign-invested enterprises (see Table 2), accounting for $2.9 \%$ of total enterprises operating in almost all sectors in Vietnam. Foreign-invested enterprises have bright prospect which create room to increase revenue from this dynamic and highly efficient economic sector.

Revenue from non-state sector also tended to increase and accounted for a relatively high proportion in the state budget revenue, averaging $16.4 \%$ for the period 2000-2017. The increase in state budget revenue from private enterprises was mainly due to the increase in the number of private enterprises established and effectiveness in operation of this sector. The number of private enterprises increased rapidly, currently Vietnam has 543,035 private enterprises (see Table 2 ), accounting for $96.9 \%$ of total enterprises. Private enterprises are now affirmed by the Vietnamese government as an important motivation of the economy. This is a big milestone in mindset and outlook of Vietnam on the role of the private sector. The private sector had only been officially recognized in Vietnam since 1986.

Table 2: Number of enterprises in Vietnam

\begin{tabular}{|l|l|l|l|l|l|l|l|l|}
\hline Year & $\mathbf{2 0 0 0}$ & $\mathbf{2 0 0 1}$ & $\mathbf{2 0 1 0}$ & $\mathbf{2 0 1 3}$ & $\mathbf{2 0 1 4}$ & $\mathbf{2 0 1 5}$ & $\mathbf{2 0 1 6}$ & $\mathbf{2 0 1 7}$ \\
\hline State-owned enterprise & 5,759 & 5,355 & 1,801 & 1,590 & 1,470 & 1,315 & 1,276 & 1,204 \\
\hline Non-state enterprise & 35,004 & 44,314 & 270,311 & 361,403 & 389,810 & 429,230 & 489,781 & 543,035 \\
\hline $\begin{array}{l}\text { Foreign-invested } \\
\text { enterprise }\end{array}$ & 1,525 & 2,011 & 7,248 & 10,220 & 11,046 & 11,940 & 14,002 & 16,178 \\
\hline Total & 42,288 & 51,680 & 279,360 & 373,213 & 402,326 & 442,485 & 505,059 & 560,417 \\
\hline
\end{tabular}

Source: General Statistics Office of Vietnam

Besides taxes, state agencies and public service providers as assigned by competent state agencies collect fees from organizations and individuals. Revenue from public service fees of Vietnam was relatively stable, averaging $6.2 \%$ of total domestic revenue for the period 2000-2017. Collected fees contribute an important part to compensate the costs of providing public services.

Revenue from land and houses accounted for $12.9 \%$ of total domestic revenue on average. This revenue reflects the exploitation of state-owned assets such as proceeds from the disposal of state-owned assets (e.g. houses, offices, etc.), transfer of land use rights, land rental and state-owned house rental, etc. Although there has been an increase in quantity and proportion in the total domestic revenue from land and houses, this revenue reflects the unsustainability due to its inability to regenerate. The state must dispose of a part of state-owned resources for current expenditure.

Custom duty revenue includes export and import duties, special consumption tax, surtax on import, value added tax on imports. Custom duty revenue relates to import and export activities. Custom duty revenue of Vietnam has increased in volume, but its proportion in total state budget revenue tends to decrease (see Figure 2). This revenue accounted for $19.3 \%$ of the state budget revenue for the period 2000-2017. Currently, custom duty revenue ranks second on the scale, following domestic revenue. Custom duty revenue is impacted in two opposite directions. The first direction which increases revenue is the expansion of international trade activities of Vietnam. Import-export turnover of Vietnam saw strong growth (see Figure 3). The year-over-year growth rate of custom duty revenue is $16.4 \%$ on average mainly due to the growth of import-export turnover. The second direction which reduces the custom duty revenue is the reduction of tariffs according to Vietnam's commitments when participating in regional and world trade organizations, as well as bilateral and multilateral trade agreements. The reduction of tariffs declines the rate of mobilization on imported and exported goods and services. The result of statistical tests shows that the impact of custom duty revenue on Vietnam's economic 
growth in the period 2000-2017 is invisible. This result is consistent with the research of Nantob (2014) and Muriithi (2013) in which they were of opinion that tax on international trade or import duty had negative impacts on economic growth. The increase in the volume of custom duty revenue may restraint Vietnam's economic development due to slowing down international trade activities. Promoting international trade may increase government revenue (Gnangnon, 2017).

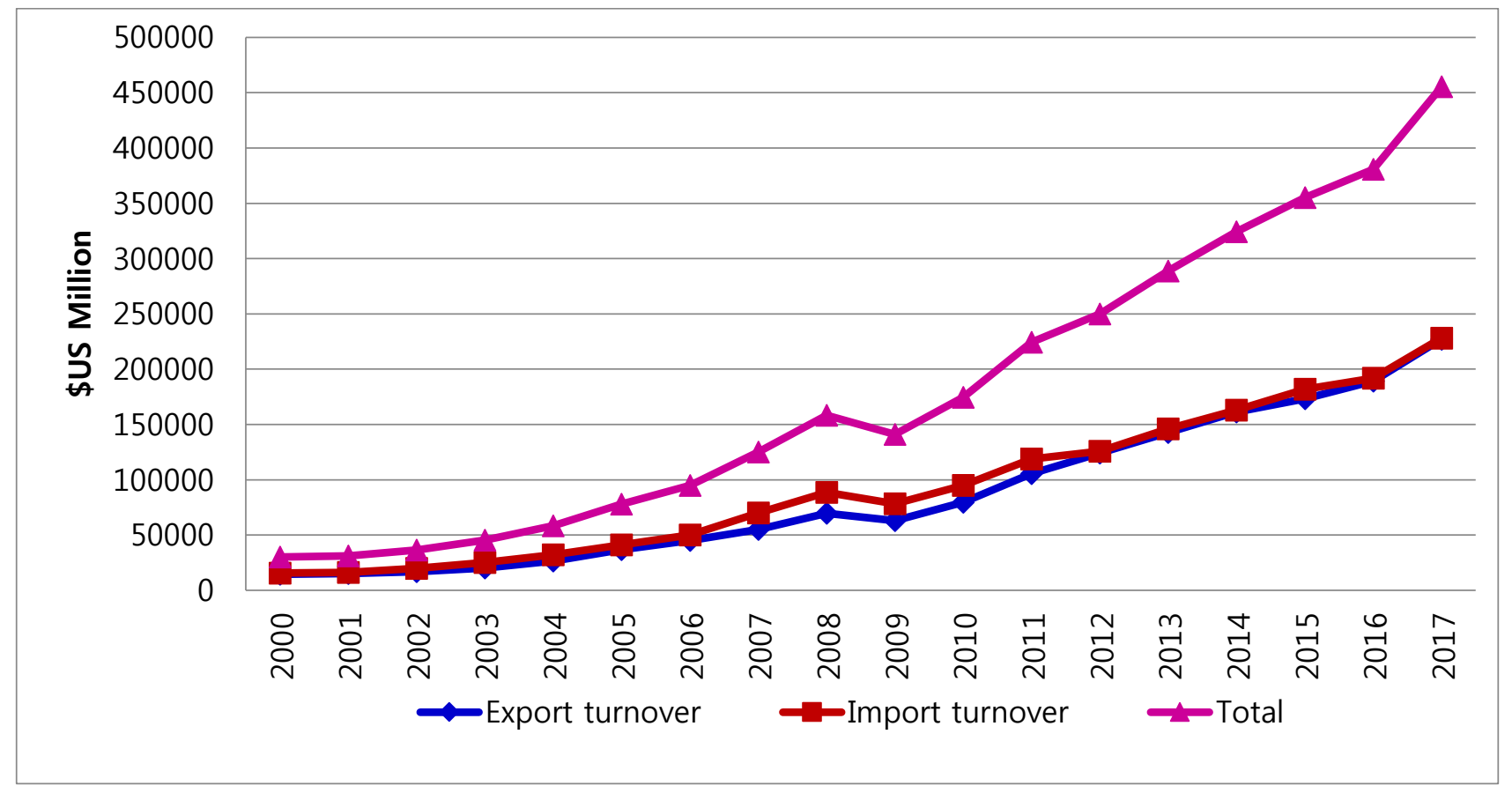

Source: General Statistics Office of Vietnam

Figure 3: International trade of Vietnam

Crude oil used to play an important role in the Vietnamese economy as it contributed nearly $1 / 3$ of the state budget revenue (reaching the highest proportion of $29.6 \%$ in 2006). Oil revenue accounted for an average proportion of $18.2 \%$ of the state budget revenue for the period 2000-2017, but tended to decrease rapidly, especially in recent years (see Figure 2). In 2017, oil revenue only accounted for $3.8 \%$ of the state budget revenue. Oil revenue fluctuates and depends mainly on crude oil prices in the world market. The erratic fluctuation of crude oil prices in the world over the past years made the actual revenue from crude oil much different from the estimation (see Table 3). This impacted the state budget expenditure because the revenue did not reach the budget estimation approved by the National Assembly of Vietnam. The result of statistical tests affirms the positive role of oil revenue in Vietnam's economy in the period 20002017 , in line with the research results of Raifu and Raheem (2018). However, state budget revenue should not depend heavily on non-renewable resources. World crude oil price, volatile factor which is extremely difficult to predict accurately, also affects the sustainability of state budget revenue.

Table 3: Comparison of estimation and execution crude oil prices

\begin{tabular}{|l|l|l|l|l|l|l|l|}
\hline Einancial Year & $\mathbf{2 0 1 1}$ & $\mathbf{2 0 1 2}$ & $\mathbf{2 0 1 3}$ & $\mathbf{2 0 1 4}$ & $\mathbf{2 0 1 5}$ & $\mathbf{2 0 1 6}$ & $\mathbf{2 0 1 7}$ \\
\hline Estimation price & 77 & 85 & 90 & 98 & 100 & 60 & 50 \\
\hline Execution price & 102 & 116.5 & 115 & 107.3 & 56.2 & 43.6 \\
\hline
\end{tabular}

Source: Ministry of Finance of Vietnam

Grants are non-refundable aids. Vietnamese government receives grants and does not have obligation to return them to foreign donors. Non-refundable aids are mainly used to implement projects aiming at researching of policies, institutions, technique, competence; improving human capacity or preparing to implement other programs and projects through activities such as providing experts, training, supporting materials, documents, visiting tours, seminars, etc. The scale of grants was not large (see Figure 2 ), accounted for an average of $1.6 \%$ of the state budget 
revenue for the period 2000-2017. This revenue stream also tends to decrease in both funding volume and proportion in state budget revenue as international donors reduce the provision of grants because Vietnam has surpassed the poor country threshold. The testing result for the period 20002017 shows that grants do not have statistical significance to the Vietnamese economy. The impact of grants on economic growth is invisible. This result reflects low efficiency in grant usages. There are three main reasons for this issue. Firstly, a large portion of the financial resources granted for Vietnam is paid back to foreign experts providing advisory services. Secondly, the targets of granting are sometimes not clearly defined, even not suitable with Vietnam's needs. Thirdly, since there is no obligation to repay foreign donors, Vietnam, as a receiving country, has a lax mentality in management and receipts of grants even if their funding objectives are unclear or inappropriate.

\section{Conclusion}

This study uses the ordinary least-squares method to analyze the relationship between state budget revenue and components of state budget revenue and Vietnam's economic growth in the period 2000-2017. The results of regression and statistic tests show that state budget revenue has a positive impact on the economy of Vietnam. The state budget collection policy of Vietnam has contributed to economic growth. The statistical tests also show that state budget revenue components have different influences on the economy. Domestic revenue and crude oil revenue are statistically significant, while the impact of custom duty revenue and grants on the economy is invisible. Vietnamese government needs to restructure the state budget revenue to increase the effectiveness and efficiency of the state budget revenue to the economy.

\section{Recommendations}

In order to improve and enhance the effectiveness and efficiency of state budget revenue, based on empirical research results, some recommendations are proposed as follows:

Firstly, Vietnam should reduce the state budget deficit and maintain under 4\% GDP to release the pressure on state budget revenue increase.

Secondly, Vietnam should increase volume and proportion of domestic revenue to the state budget revenue. Domestic revenue would be improved towards covering all revenue sources, expanding the collection bases, reducing the revenue mobilization ratio in order to boost production development and encourage private investment, cutting down the revenue from sale of state-owned assets.

Thirdly, Vietnam should pay attention to improve the capacity in analyzing and forecasting the world crude oil prices to minimize the negative impact of world oil prices on state budget revenue. The exploitation of crude oil should be at a reasonable level to avoid the exhaustion of this nonrenewable resource and the point of drilling should be considered to keep pace with the fluctuations of the world crude oil market.

Fourthly, Vietnam should actively cut down the tariff according to the committed international agreements to boost the economy. In addition, Vietnam needs to continue expanding international trade through negotiating and concluding of bilateral and multilateral free trade agreements.

Finally, Vietnam should reduce non-refundable aids. The objectives of projects financed by aid resources should be clearly defined and these projects should be strictly managed to ensure the effective usage of the grants.

\section{References}

Babatunde, O. A., \& Ibukun, A. O. (2016). Taxation and economic growth in Nigeria. Asian Journal of Economic Modelling, 4(4), 199-210. DOI: 10.18488/journal.8/2016.4.4/8.4.199.210

Dladla, K., \& Khobai, H. (2018). The impact of taxation on economic growth in South Africa (MPRA Paper No. 86219). Retrieved from https://mpra.ub.unimuenchen.de/86219/

Gnangnon, S. K. (2017). Multilateral trade liberalization and government revenue. Journal of Economic Integration, 32(3), 586-614. http://dx.doi.org/10.11130/jei.2017.32.3.586

Muriithi, C. (2013). The relationship between government revenue and economic growth in Kenya. International Academic Journal of Information Sciences and Project Management, 1(1), 87-109. Retrieved from http://www.iajournals.org/articles/iajispm_v1_i1_87_109 .pdf

Nantob, N. (2014). Taxes and economic growth in developing countries: A dynamic panel approach (MPRA Paper No. 61346). Retrieved from https://mpra.ub.uni-muenchen.de/61346/

Ofoegbu, G. N., \& Akwu, D. O. (2016). Empirical analysis of effect of tax revenue on economic development of Nigieria. International Journal Asian Social Science, 6(10), 604-613. DOI: 10.18488/journal.1/2016.6.10/1.10.604.613

Raifu, I. A., \& Raheem, A. N. (2018). Do government revenues matter for economic growth? Evidence from Nigeria. European Journal of Government and Economics, $\quad 7(1), \quad 60-84$. DOI: https://doi.org/10.17979/ejge.2018.7.1.4333

Romer, C. D., \& Romer, D. H. (2010). The macroeconomic effects of tax changes: Estimates based on a new measure of fiscal shocks. American Economic Review, 
100(3), 763-801. Retrieved from http://www.aeaweb.org/articles.php?doi=10.1257/aer.100 .3 .763

Saidin, N. A. B., Basit, A., \& Hamza, S. M. (2016). The role of tax on economic growth. International Journal of Accounting \& Business Management, 4(2), 242-250.
DOI: $10.24924 / \mathrm{ijabm} / 2016.11 / \mathrm{v} 4 . \mathrm{iss} 2 / 242.250$

Takumah, W. (2014). Tax revenue and economic growth in Ghana: A cointegration approach (MPRA Paper No. 58532). Retrieved from http://mpra.ub.unimuenchen.de/58532/ 